\title{
Kryzys w Mali jako wyzwanie dla wspólnej polityki zagranicznej, bezpieczeństwa i obrony Unii Europejskiej w latach 2012-2014
}

\section{Wprowadzenie}

Działania UE w obliczu trwającego w ostatnich latach kryzysu w Mali wyraźnie uwydatniają zarówno możliwości, jak i granice unijnej zdolności zarządzania kryzysowego. W połowie stycznia 2013 roku Francja rozpoczęła interwencję militarną skierowaną przeciwko islamskim rebeliantom w północnym Mali, poszukując jednocześnie politycznego rozwiązania konfliktu. Rebelia na północy i wojskowy zamach stanu na południu kraju w przeciagu pierwszych miesięcy 2012 r. spowodowały, że z jednej z niewielu zachodnioafrykańskich, jak się okazało pozornie stabilnej demokracji, Mali stało się nowym międzynarodowym wyzwaniem dla bezpieczeństwa regionu. Zagrożenie to potęguje współwystępowanie słabo rozwiniętej państwowości, wewnętrznych etnicznych, politycznych i społecznych konfliktów, z jednej strony, oraz wykorzystanie istniejącego rozproszenia przez inspirowanych islamem terrorystów, z drugiej strony. W konsekwencji dotyka ono nie tylko danego kraju, ale rozprzestrzenia się na państwa Afryki Zachodniej, a szczególnie strefy Sahel. Poza pogłębiającym się kryzysem humanitarnym, pogarszanie się sytuacji w dużym stopniu zagraża interesom europejskim, czego przykładem jest wzmożona fala uchodźców, akty terroru, czy wzrost przestępczości zorganizowanej.

Od 1999 r. Unia Europejska dąży do rozwoju wojskowych i cywilnych komponentów Wspólnej Polityki Bezpieczeństwa i Obrony, które majajej pozwolić na aktywne kształtowanie procesów związanych z zapobieganiem, zaprowadzaniem pokoju i stabilizowaniem sytuacji kryzysowych, konfliktowych i pokonfliktowych. Temu celowi podporządkowane zostały operacje zarządzania kryzysowego o charakterze cywilnym, wojskowym i cywilno-wojskowym. Obecnie (stan na czerwiec 2015, EEAS, 2015a) w ramach Wspólnej Polityki Bezpieczeństwa i Obrony Unia Europejska realizuje 17 misji (w tym 11 to misje cywilne).

Europejska Strategia Bezpieczeństwa z 2003 r. podkreśla konieczność zwiększenia „aktywności w dążeniu do naszych celów strategicznych. Ma to zastosowanie do całego zakresu będących w naszej dyspozycji instrumentów zarządzania kryzysowego i zapobiegania konfliktom, w tym do działań politycznych, dyplomatycznych, wojskowych i cywilnych, handlowych i rozwojowych. Konieczne są aktywne polityki, by przeciwdziałać nowym dynamicznym zagrożeniom. Musimy rozwinąc strategiczną kulturę sprzyjającą wczesnej, szybkiej oraz, w koniecznych przypadkach, zdecydowanej interwencji" (Europejska Strategia Bezpieczeństwa, 2003). Opracowana przez Eu- 
ropejską Agencję Obrony w 2009 r. broszura analizuje wyzwania, którym Europa w przyszłości będzie musiała stawić czoła i niezbędny w związku z tym rozwój unijnych zdolności obronnych. Ponieważ „świat w 2025 r. będzie bardziej zróżnicowany, bardziej współzależny oraz coraz bardziej nierównomierny" (European Defence Agency, 2006; 2009, s. 20). I nawet w przypadku gdy Europa stanie się mniej niezależna na arenie międzynarodowej, „a bezpośrednie sąsiedztwo bardziej problematyczne, interwencja militarna stanie się tym bardziej kwestią ostrożną”. Tzw. „efekt CNN” będzie potęgował awersję społeczeństw do militarnego zaangażowania poza granicami kraju. „Rządy i społeczeństwa w coraz większym stopniu skupione na bezpieczeństwie wewnętrznym i społecznej spójności będą bardziej niezdecydowane na podjęcie kontrowersyjnej interwencji zewnętrznej, głównie w regionach, z których pochodzi największa liczba migrantów. Rosnąca proliferacja zdolności nuklearnych, biologicznych i chemicznych może jeszcze bardziej komplikować koszty interwencji" (European Defence Agency, 2009, s. 21). Nasilające się problemy z bezpieczeństwem wewnętrznym wpłyną na erozję rozróżnienia pomiędzy tym co postrzegamy jako płaszczyznę ,,obrony” a tym co rozumiane jest jako „bezpieczeństwo” przez państwa członkowskie (European Defence Agency, 2009, s. 21).

\section{Uwarunkowania i ramy międzynarodowego zaangażowania w Mali}

Konflikt w północnym Mali jest rezultatem dwóch różnych, ale ściśle ze sobą powiązanych kryzysów: rywalizacji elit grup plemiennych, z których niektóre zawarly sojusz z uzbrojonymi ekstremistami oraz nieudolności i bezradności rządu w Bamako, od kiedy w marcu 2012 ówczesny prezydent Amadou Toumani Touré został obalony w wyniku przewrotu wojskowego. Napięcia pomiędzy osiadłą na południu ludnością Mali a Tuaregami, ludem nomadzkim zamieszkującym północną część kraju siegają uzyskania przez Mali niepodległości w 1960 r. Do ich eskalacji dochodziło na początku lat 90. i w latach 2006-2009. Tuaregowie, których liczebność w Mali siega ok. 300 tys., posiadając odrębną kulturę opartą na matriarchacie, dążą do secesji i utworzenia suwerennego państwa Azawad na terenie bogatego w złoża surowcowe północnego Mali. Ich liczebność - w Mali, Nigrze, Burkina Faso, Algierii i Libii - szacuje się na około 6 milionów osób. Powstania Tuaregów mające na celu uzyskanie terytorialnej i kulturowej niezależności miały miejsce w 1990, 2006 i ostatecznie w 2012 roku (Dickow, 2014). Sytuacja zaostrzyła się po wydarzeniach Arabskiej Wiosny i upadku reżimu libijskiego w sierpniu 2011 r. Napływ dawnych najemników libijskich i skorumpowanie malijskich elit rządzących ${ }^{2}$ (por. Lacher, Tull 2013; Crisis in Mali, 2014) pozwoliły na wzmocnienie znacznej części separatystycznych i islamskich bojówek w regionie, skupionych $\mathrm{w}$ takich organizacjach, jak Al-Qaida Islamskiego Maghrebu (AQIM), jej odłamu Ruchu na Rzecz Jedności i Dżihadu w Afryce Zachodniej (MUJAO), Ansar ad-Dine (Obrońcy Wiary) oraz Narodowym Ruchu Wyzwolenia Azawadu (MNLA).

1 Wplyw przekazów medialnych na dzialania podejmowane przez decydentów politycznych.

2 Zamieszanie malijskich elit rządowych w kryminalną działalność pozwoliło na wzmocnienie pozycji AQIM na północy Mali (przemyt narkotyków, porwania dla okupu). 
Każda z tych grup miała swoje cele odnośnie do terytorium Mali: MUJAO dążyło do objęcia dżihadem nie tylko na Mali, ale całej Zachodniej Afryki, AQIM zapowiadało wprowadzenie prawa islamskiego i wyzwolenie Malijczyków spod panowania francuskich kolonialistów.

Rosnące niezadowolenie członków malijskiej armii wobec polityki rządu w Bamako w obliczu rebelii doprowadziło w marcu 2012 r. do obalenia prezydenta Amadou Toumani Toure. Wywołany w ten sposób polityczny chaos pozwolił na przejęcie kontroli nad północnym Mali przez połączone siły MNLA i Ansar Dine oraz ogłoszenie 6 kwietnia 2012 r. niepodległego państwa Azawad i wprowadzenie szarijatu. Wojna domowa spowodowała ucieczkę setek tysięcy Malijczyków z północy na południe i do krajów sąsiedzkich, zaostrzając regionalny kryzys żywnościowy w społecznościach przyjmujących. Niestabilna sytuacja polityczna blokowała skuteczne działania regionalne i międzynarodowe przeciwko okupacji północy kraju. W styczniu 2013 r. militarna interwencja Francji powstrzymała ofensywę rebeliantów i pozwoliła na odzyskanie zajętych regionów. W wyniku demokratycznych wyborów przeprowadzonych w lipcu i sierpniu 2013 r. w drugiej turze prezydentem został Ibrahim Boubacar Keita. W dalszym ciagu jednak sytuacja w północnym Mali jest niestabilna, dochodzi do aktów przemocy ze strony tuareskich rebeliantów i islamskich ekstremistów. Pomiędzy 27 maja i 15 września 2014 r. siły powstańcze przeprowadziły 27 ataków na personel i oddziały ONZ misji MINUSMA(Crisis in Mali, 2014). Od 2013 r. śmierć poniosło ponad 40 żołnierzy misji (Deutsche Welle, 2015a). Prowadzone od lipca 2014 r. przez rząd Algierii, Unię Afrykańską (UA), ECOWAS i Specjalnego Przedstawiciela Sekretarza Generalnego ONZ ds. Mali negocjacje pokojowe pomiędzy rządem Bamako a tuareskimi rebeliantami doprowadziły do podpisania w dwóch turach 15 maja i 20 czerwca 2015 r. porozumienia pokojowego przez wszystkie strony (Deutsche Welle, 2015b). Obejmuje ono uznanie rządu w Bamako oraz przyznanie większych praw północnemu Mali. Niemniej decydująca dla jego powodzenia jest akceptacja wśród tuareskiej społeczności północnego Mali.

Mimo recesji spowodowanej wojną domową, według danych Afrykańskiego Banku Rozwoju z 2015 r., od 2013 r. malijska gospodarka odnotowuje wzrost gospodarczy, który w 2014 r. osiaggnął 5,8\%, a w 2015 r. szacuje się że ma on osiagnąć 5,4\%. Niemniej kryzys wpłynął na zwiększenie się odsetka ludności żyjącej w skrajnym ubóstwie z 41,7\% w 2011 do $42,7 \%$ w $2012 \mathrm{r}$. W dalszym ciagu bardzo trudna jest sytuacja ludności na północy kraju. Ataki ekstremistów na pozycje stacjonowania malijskiej armii i międzynarodowych sił pokojowych, a także walki pomiędzy poszczególnymi bojówkami oraz napływ uchodźców i przesiedlonych powracających do domu zaostrzają istniejący tam już kryzys żywnościowy (pomocy żywnościowej wymaga 1,7 mln osób, w tym 260 tys. pilnie). Napływ uchodźców jest również konsekwencją kryzysu w Republice Środkowej Afryki, w wyniku którego ponad 200 osób ubiegało się o azyl w Mali, w tym 190 uzyskało status uchodźcy (UNHCR Mali, 2015). Mali według rankingu Fund of Peace z 2014 r. znajduje się na 36. pozycji w gronie państw o bardzo wysokich obawach związanych z niestabilnością. W klasyfikacji państw według wskaźnika rozwoju społecznego HDI (Human Development Index) w 2013 r. Mali zajmowała 176 miejsce wśród 187 ujętych w niej państw. Około 3/4 Malijczyków utrzymuje się za niespełna 2 dolary dziennie. W odpowiedzi na zaostrzającą się sytuację w 2014 r. 
społeczność międzynarodowa opracowała strategiczny plan pomocy humanitarnej, zakładający wsparcie w wielkości $481 \mathrm{mln}$ USD (Mali, 2015).

Eskalująca w styczniu $2012 \mathrm{r}$. sytuacja w Mali wprawdzie znalazła się w centrum zainteresowania społeczności międzynarodowej w połowie tego roku (ONZ, UE, NATO, Wspólnoty Gospodarczej Państw Afryki Zachodniej (ECOWAS), Unii Afrykańskiej), niemniej wojskowy zamach stanu w marcu utrudnił i odłożył w czasie planowane środki zaradcze. Intensywne wysiłki mediacyjne prowadzone przez Wspólnotę Gospodarczą Państw Afryki Zachodniej pozwoliły na powrót w kwietniu tymczasowego rządu wraz z prezydentem Dioncounda Traoré. Międzynarodowa interwencja przewidywała opracowanie tzw. mapy drogowej oraz równoległe funkcjonowanie w ramach mandatu Rady Bezpieczeństwa wojskowej misji wsparcia ECOWAS oraz unijnej misji szkoleniowej (z wyłączeniem udziału w działaniach zbrojnych). Dopiero po zaplanowanym na wrzesień 2013 r. uruchomieniu tych środków, zamierzano podjąć kroki do odzyskania pólnocnego Mali.

Ramy interwencji stanowily rezolucje Rady Bezpieczeństwa ONZ nr 2071 z 12 października 2012 r. oraz nr 2085 z 20 grudnia 2012 r. Rezolucja 2071 wzywała do „,wprowadzania tak szybko jak to możliwe skoordynowanej pomocy, szkoleń i budowania zdolności wspierających armię i siły bezpieczeństwa w Mali" (UN Security Council, 2012a). Rezolucja 2085 dawała mandat dla interwencji AFSIMA (UN Security Council, 2012b). Stwierdzono, że sytuacja w Mali stanowi zagrożenie dla międzynarodowego pokoju i wymaga podjęcia środków przewidzianych w rozdziale VII Karty NZ. Wobec zaostrzającej się sytuacji i ofensywy ekstremistów i terrorystów w południowo-zachodnim Mali rezolucja 2085 RB podkreślała konieczność obrony przed rosnącym zagrożeniem terrorystycznym w Mali. Mandat ONZ zawieral komponent militarny - walka z islamistami, humanitarny - ochrona uchodźców oraz polityczny przywrócenie w kraju konstytucyjnych rządów prawa. Przewidywano podjęcie działań w dwóch etapach:

1) ustanowienie w Mali na jesieni 2013 r. misji wojskowej ECOWAS pod afrykańskim dowództwem z udziałem krajów zachodniej Afryki, takich jak Benin, Burkina Faso, Ghana, Gwinea, Niger, Nigeria i Togo (AFSIMA Afican-led International Support Mission in Mali), której zadaniem było przywrócenie zdolności do obrony i utrzymania bezpieczeństwa malijskim siłom zbrojnym, wsparcie Mali w odzyskiwaniu terytorialnej kontroli na północy i pomoc malijskim władzom w ich przejęciu odpowiedzialności za ochronę ludności cywilnej. A także zaangażowanie UE w budowę, szkolenie i wyposażenie armii malijskiej (Rada UE 2012);

2) odzyskanie okupowanego terytorium i przywrócenie go rządowi w Bamako przez przygotowaną armię malijską wspartą przez misję AFSIMA.

Odległa w czasie reakcja społeczności międzynarodowej pozwoliła ekstremistom na przejęcie kontroli nad dalszymi częściami północnego Mali. Brak rezultatów rozpoczętego pod parasolem ECOWAS procesu mediacyjnego oraz słabość malijskiej armii przesądził o konieczności natychmiastowego wysłania misji AFSIMA $^{3}$, która jednak

36000 żolnierzy z co najmniej 8 zachodnioafrykańskich państw: Beninu, Burkina Faso, Ghany, Gwinei, Nigru, Nigerii, Senegalu i Togo. Włączył się również Czad, jako jedyne państwo niebędące członkiem ECOWAS, postawił do dyspozycji największy kontyngent 2000 żołnierzy. Mauretania 
nie była w stanie samodzielnie wypełnić swojego mandatu. Wobec bezpośredniego zagrożenia stolicy Bamako przez bojówki AQMI (Al. Qaida Islamskiego Maghrebu) i MNLA (Ruch na Rzecz Utworzenia Azawadu) prezydent Traoré poprosił Francję o interwencję. Podobnie jak państwa Afryki Zachodniej, Francja obawiała się, że kontrolowane przez islamistów terytorium stanie się ośrodkiem radykalnych ekstremistów i jednocześnie transnarodowej przestępczości zorganizowanej, zagrożeniem dla już kruchej stabilności regionalnej, w bezpośrednim sąsiedztwie Europy.

11 stycznia 2013 r. Francja rozpoczęła w Mali wojskową operację Serval. Wsparły ją oddziały z Czadu, które wkroczyły do Mali 17 stycznia. Dzięki swoim wpływom ze sprzedaży ropy Czad należy do najlepiej uzbrojonych państw w regionie. Prezydent tego kraju Idriss Déby naciskał na interwencję wojskową, by zapobiec rozprzestrzenieniu się islamskich sił w regionie Sahel. Pomiędzy 26 a 30 stycznia francuska kampania lotnicza wyparła ekstremistów z Timbuktu, Kidal i Gao. Odzyskano kontrolę nad północnym Mali. W Gao pozostawiono liczącą 1000 żołnierzy grupę bojową wojsk francuskich. Dla wzmocnienia bezpieczeństwa całego Sahelu 1 sierpnia 2014 r. Francja rozpoczęła misję wojskową pod kryptonimem Barkhane. W przeciwieństwie do operacji Serval francuscy żołnierze zostali rozmieszczeni na terenie pięciu państw: Burkina Faso, Czadu, Mali, Mauretanii i Nigru. Misja ma pomóc miejscowym władzom i siłom bezpieczeństwa $\mathrm{w}$ walce $\mathrm{z}$ grupami terrorystycznymi oraz zapobiec wzrostowi sił islamskich ekstremistów w północnej Afryce. Stała siedziba misji została ustanowiona w stolicy Czadu N'Djamena (Crisis in Mali, 2015).

$\mathrm{Na}$ mocy rezolucji Rady Bezpieczeństwa 2100 z 25 kwietnia 2013 r. (UN Security Council, 2013) powołana została Integracyjno-Stabilizacyjna Misja Narodów Zjednoczonych w Mali (United Nations Multidimensional Integrated Stabilization Mission in Mali, MINUSMA), której znaczną część tworzyły oddziały ECOWAS wcześniej wspierające francuską interwencję (Crisis in Mali, 2015). Docelowo jej liczebność miała osiagnąć 11200 żołnierzy i 1440 policjantów. Od 1 lipca 2013 r. MINUSMA zabezpiecza północne Mali, jest odpowiedzialna za ochronę cywili „,w przypadku bezpośredniego zagrożenia przemocą fizyczną”, wobec „potrzeb ofiar przemocy seksualnej i o podłożu płciowym w konfliktach zbrojnych" i ma za zadnie monitorować sytuację, kontrolować $i$ informować RB o jakichkolwiek naruszeniach praw człowieka i międzynarodowego prawa humanitarnego. 24 czerwca 2014 r. RB przyjęła rezolucję 2164, która przedłużała mandat MINUSMy o rok, a także wyposażała w większe kompetencje Specjalnego Przedstawiciela Sekretarza Generalnego ONZ w Mali (UN Security Council, 2014). Po podpisaniu 13 czerwca 2013 r. porozumienia między rządem centralnym a MNLA i Wysoką Radą Jedności Azawadu, 28 lipca 2013 r. przeprowadzona została pierwsza tura wyborów prezydenckich. W drugiej turze 11 sierpnia zwyciężył były premier Ibrahim Boubacar Keïta, zaprzysiężony na prezydenta 4 września. Formalnie Mali rozpoczęło proces normalizacji - do zadań nowych władz należało wypracowanie porozumienia pomiędzy południem i północa, reforma sił bezpieczeństwa, walka $\mathrm{z}$ biedą $\mathrm{i}$ bezrobociem, rozbudowa infrastruktury.

i Algieria odmówily udziału w misji z obawy przed przeniesieniem się konfliktu na ich terytorium. W Mauretanii ponadto przeważało przeświadczenie, że jest to ofensywa czarnych żołnierzy z Mali i zachodniej Afryki przeciwko białym grupom ludności w północnym Mali. 


\section{Ramy polityki Unii Europejskiej wobec Mali}

Afryka, zwłaszcza Subsaharyjska, jest drugim po Półwyspie Bałkańskim obszarem szczególnego zainteresowania Unii Europejskiej, zarówno jako adresat unijnej pomocy rozwojowej i humanitarnej, jak i działań w zakresie reagowania kryzysowego.

Głównie z inicjatywy Francji ${ }^{4}$, UE prowadziła i prowadzi w Afryce misje wojskowe: w 2003 r. Artemis DR Kongo; 2006 EUFOR DR Kongo, 2008-2009 EUFOR Czad i Republika Środkowej Afryki, EUFOR Republika Środkowej Afryki (2014), obecnie trwają EUTM Somalia (od 2010), EUMAM Republika Środkowej Afryki (od 2015), EU NAFVOR ATALANTA (od 2008), EUTM Mali (od 2013) (stan na czerwiec 2015, EEAS, 2015). Podobnie cywilne operacje reagowania kryzysowego prowadzone były lub są w Demokratycznej Republice Kongo, Sudanie i Somalii, Gwinei-Bissau, Libii, Nigrze i Mali (EEAS, 2015).

W związku ze swoim położeniem w sercu regionu Sahel Mali jest częścią przyjętej w 2011 r. Strategii bezpieczeństwa i rozwoju Sahel. Wyznacza ona cztery strategiczne kierunki działania UE: 1) rozwój, dobre rządy, rozwiązywanie konfliktów wewnętrznych; 2) wspólpraca polityczna i dyplomatyczna; 3) bezpieczeństwo i państwo prawa; 4) walka z ekstremizmem i radykalizacją prowadzącą do przemocy. Strategia ta obejmuje również Niger i Mauretanię, ma na celu wsparcie wysiłków tych państw na rzecz rozwoju gospodarczego, pomagając im w kreowaniu bezpiecznego środowiska. Temu jednemu z najbiedniejszych regionów świata, borykającemu się z ubóstwem, zmianami klimatu, kryzysem żywnościowym, dynamicznym wzrostem ludności, niestabilnymi rządami, korupcją podwyższoną podatnością na zagrożenia związane z radykalnym ekstremizmem, nielegalnym handlem i terroryzmem, przypisuje się szczególne znaczenie ze względu na położenie na granicy pomiędzy światem arabskim a Afryką Subsaharyjską. Jak podkreśla strategia ,problemy dotykające Sahelu nie tylko oddziałują na lokalną ludność, ale mają rosnący wpływ na interesy europejskich obywateli" (EEAS, 2011). Eksponuje współzależność pomiędzy bezpieczeństwem a rozwojem, wpływ dysfunkcyjnych rządów na stabilność regionu i zdolność do przezwyciężania nasilających się zagrożeń ubóstwa i braku bezpieczeństwa. "Ubóstwo kreuje nieodłącznie niestabilność, która może mieć wpływ na niekontrolowane fale migracji" (EEAS, 2011). Szczególnie aktywność AQIM, którego ,sanktuarium" stało się północne Mali, skierowane jest przeciwko interesom Zachodu. Tym samym eskalacja kryzysu

${ }^{4}$ W przeciwieństwie do innych mocarstw kolonialnych, jak Wielka Brytania, Belgia czy Portugalia, Francja nigdy nie wycofała się militarnie z Afryki na południe od Sahary. Po tym jak francuskie kolonie na początku lat 60 . odzyskały niepodległość wciąż angażowała się w rozwiązywanie miejscowych konfliktów. Jednocześnie Paryż wspierał najczęściej autorytarne reżimy zarówno przed atakami z zewnątrz, jak i wewnętrznymi przeciwnikami, utrzymując tym samym wladzę. W latach 90. rola Francji jako ,żandarma Afryki" została zachwiana. W latach przed ruandyjskim ludobójstwem z 1994 r. Francja wspierala reżim Hutu. Dokonane po morderstwie prezydenta Habyarimanasa w 1994 r. przez bojówki Hutu masowe morderstwa czlonków grupy Tutsi (zabito ok. 800 tys. osób) wywolały międzynarodową falę krytyki i zarzut wspólodpowiedzialności wobec Francji. Po tym incydencie Paryż utrzymywał dystans wobec militarnego zaangażowania się na kontynencie afrykańskim do czasu trwającej od 2002 r. interwencji francuskich wojsk na Wybrzeżu Kości Słoniowej w ramach operacji Licorne ,jednorożec". 
w tym kraju wywołała zwiększone obawy co do bezpieczeństwa całego regionu Sahel (EEAS, 2011).

Mali jest ważnym partnerem UE w Afryce Zachodniej, już od 1958 r. Wspólnoty miały tam swoje przedstawicielstwo. Do najważniejszych przesłanek unijnego zaangażowania należą zagrożenie terroryzmem i destabilizacja regionu Sahel. Tym samym realizowane jest ono na płaszczyźnie politycznej, bezpieczeństwa, pomocy rozwojowej i humanitarnej. W konkluzjach Rady UE w sprawie Mali z 10 grudnia 2012 r. zatwierdziła ustanowienie na zaproszenie rządu Mali i w ramach mandatu ONZ szkoleniowej misji wojskowej w ramach WPBiO, jako jednego z elementów ,wszechstronnego podejścia" UE w całym regionie (Rada UE, 2012). Jej celem miała być poprawa efektywności operacyjnej malijskich sił zbrojnych, z naciskiem na poszanowanie przez nie praworządności i międzynarodowych standardów prawa humanitarnego, ochrony ludności cywilnej i praw człowieka. Na mocy decyzji Rady UE z 18 stycznia 2013 r. uruchomiona została wojskowa misja szkoleniowa EUTM Mali, z wyłączeniem udziału w działaniach bojowych. Jej mandat obejmował wsparcie malijskich władz w: przywróceniu konstytucyjnego i demokratycznego porządku oraz wdrożenie mapy drogowej (m.in. przeprowadzenie demokratycznych wyborów), odzyskanie pełnej kontroli władz nad całym terytorium oraz zneutralizowanie zagrożenia przestępczością zorganizowaną i terroryzmem. Początkowo została ona uruchomiona na 15 miesięcy, $15 \mathrm{kwietnia}$ 2014 r. Rada do Spraw Zagranicznych przedłużyła jej mandat o 24 miesiące do 18 maja 2016 r. W misji uczestniczą 24 państwa (22 kraje UE) ${ }^{5}$ W jej skład wchodzi ok. 200 instruktorów, zatrudnionych w obozie szkoleniowym w Koulikoro, a także siły wsparcia i bezpieczeństwa łącznie 439 osób. Koszt przedhużonego mandatu misji to $27,7 \mathrm{mln}$ euro (EEAS, 2015b). Jest on finansowany z wkładów państw członkowskich oraz za pośrednictwem mechanizmu ATHENA ${ }^{6}$. Zadaniem EUTM Mali jest przeszkolenie malijskich żołnierzy, tak by byli w stanie skutecznie przywrócić stabilność w kraju. Nacisk położny jest na szkolenie operacyjne, dowodzenie i kontrolę, łańcuch logistyczny i zasoby kadrowe. Szkolone na południu kraju z zakresu budowania zdolności malijskie oddziały stacjonują następnie przez okres co najmniej sześciu miesięcy na północy. Jednakże utrzymującym się problemem, niepozwalającym na w pełni autonomiczne i niezależne działanie, jest m.in.: brak środków łączności, sprzętu chroniącego przed minami, karetek pogotowia, zbiorników na wodę, cystern paliwowych, zabezpieczenia podstawowych potrzeb (zakwaterowania, żywności, wsparcia medycznego). W związku z powyższym UE zapowiedziała prace nad poszukiwaniem bardziej długofalowego rozwiązania, pozwalającego na uzupełnienie luk i potrzeb w zakresie szkoleń i sprzętu (Komisja Europejska, Wysoki Przedstawiciel Unii do Spraw Zagranicznych i Polityki Bezpieczeństwa, 2015).

5 Austria, Belgia, Bułgaria, Czechy, Estonia, Finlandia, Francja, Niemcy, Grecja, Węgry, Irlandia, Włochy, Litwa, Łotwa, Luxemburg, Holandia, Portugalia, Rumunia, Słowenia, Hiszpania, Szwecja i Wielka Brytania + Czarnogóra i Serbia.

${ }_{6}$ Art. 41 TUE określa zasady finansowania operacji UE w zakresie zarządzania kryzysami cywilno-wojskowymi. Wydatki na działania mające wpływ na kwestie wojskowe i obronne nie są pokrywane z budżetu UE. 27 marca 2015 r. ustanowiono mechanizm zarządzania finansowaniem wspólnych kosztów operacji UE mających wplyw na kwestie wojskowe i obronne ATHENA, do którego wnoszą wkład wszystkie państwa członkowskie, za wyjątkiem Danii. 
Na spotkaniu 15 kwietnia 2014 r. ministrowie spraw zagranicznych państw członkowskich UE postanowili rozpocząc misję cywilną EUCAP Sahel Mali, która łączy szkolenia i doradztwo strategiczne oraz restrukturyzację malijskiej policji, żandarmerii i gwardii narodowej. Jej zadaniem jest wsparcie władz malijskich w przywróceniu porządku konstytucyjnego i demokratycznego, a także zapewnieniu warunków dla zaprowadzenia trwałego pokoju oraz wprowadzeniu efektywnej władzy administracyjnej. Pomoc we wdrażaniu reformy bezpieczeństwa ma m.in. służyć wzmocnieniu roli organów sądowych i administracyjnych w zarządzaniu i nadzorze malijskich sił bezpieczeństwa wewnętrznego oraz ułatwić ich rozmieszczanie na północy kraju. Na mocy decyzji Rady UE z 19 stycznia 2015 r. misja uruchomiona została 15 stycznia 2015 r. na okres 24 miesięcy (styczeń 2015-styczeń 2017). Na wydatki związane z EUCAP Sahel Mali w okresie od 15 kwietnia 2014 r. do 14 stycznia 2015 r. przewidziano $5,5 \mathrm{mln}$ euro, natomiast na okres od 15 stycznia 2015 do 14 stycznia $2016 \mathrm{r}$. - 11,4 mln euro. W skład unijnego personelu wchodzi 80 osób z 13 państw członkowskich (EEAS 2015b).

Podpisane 15 maja i 20 czerwca 2015 r. porozumienie pokojowe dotyczące Mali Unia Europejska uznała za „fundamentalne [...] dla przywrócenia pokoju, stabilności i bezpieczeństwa, poprawienia warunków życia ludności oraz odbudowy wzajemnego zaufania, które pomoże w procesie pojednania narodowego" (Rada UE, 2015b). Niemniej istotne jest „bezwarunkowe i trwałe przestrzeganie” zawieszenia broni. Państwa członkowskie pokreśliły „kompleksowe podejście do ułatwiania działań na rzecz pokoju, bezpieczeństwa i rozwoju w Mali". Z jednej strony ważną rolę we wspieraniu reformy malijskiego sektora bezpieczeństwa pełnią dwie prowadzone w ramach WPBiO misje EUTM Mali i EUCAP Sahel Mali. Z drugiej strony odbudowie państwa służą środki przeznaczone na wspólne programowanie w ramach 11. Europejskiego Funduszu Rozwoju i Instrumentu na rzecz Stabilności i Pokoju (Rada UE, 2015a, 2015b). Jednocześnie akcentuje się znaczenie regionalnego wymiaru w zapewnianiu bezpieczeństwa i dobrobytu w Mali oraz ścisłej współpracy ze wszystkimi państwami regionu Sahel i regionalnymi organizacjami.

Unia Europejska jest największym donatorem pomocy rozwojowej dla Mali. Na konferencji w sprawie pomocy rozwojowej w Brukseli 15 maja 2013 r. międzynarodowa społeczność donatorów zapowiedziała wsparcie w wysokości 3,2 mld euro (w tym $1,28 \mathrm{mld}$ to pomoc UE). Celem unijnego zaangażowania jest pomoc władzom malijskim w konsolidacji pokoju i bezpieczeństwa oraz w szerszej perspektywie w rozwiązaniu kryzysu w regionie Sahel w ścisłej współpracy z innymi regionalnymi i międzynarodowymi podmiotami.

W $2013 \mathrm{r}$. UE przyznała Mali wsparcie w wysokości $327 \mathrm{mln}$ euro i 124,6 $\mathrm{mln}$ euro ze środków 10. Europejskiego Funduszu Rozwoju (EFD). W okresie 2014-2020 w ramach 11. edycji Europejskiego Funduszu Rozwoju Mali ma otrzymać łącznie $615 \mathrm{mln}$ (EUROPAID, 2015) Środki otrzymane w ramach 10. edycji Europejskiego Funduszu Rozwoju (2008-2013) miały na celu zainicjowanie wzrostu gospodarczego i redukcję ubóstwa. Do innych priorytetowych obszarów zaliczono: proces decentralizacji rządów, politykę migracyjną oraz rozwój gospodarczy północy kraju i delty Nigru. Programy rozwojowe, które UE finansuje w Mali koncentrują się na: zaspokojeniu niezbędnych potrzeb humanitarnych, przywróceniu podstawowych usług, stabiliza- 
cji, wprowadzeniu skutecznej administracji i rządów prawa oraz tym samym stworzeniu podstaw dla dhugofalowego rozwoju. Projekty te realizowane były w ramach Planu Odbudowy Mali na lata 2013-2014, w zwiazzu z tym zwiększone zostały środki z 10. EFD z $533 \mathrm{mln}$ do $728 \mathrm{mln}$ euro (EUROPAID, 2015).

W 2013 r. środki na wsparcie różnych sektorów wyniosły $208 \mathrm{mln}$ euro. Wypłacona została pierwsza transza w obszarze budowy państwowości ( $90 \mathrm{mln}$ euro z $225 \mathrm{mln}$ euro) na wsparcie rządów i państwowej stabilności i na rzecz wyborów $(17 \mathrm{mln})$. $468 \mathrm{mln}$ euro przeznaczono na liczne projekty w zakresie dostępu co czystej wody i sanitariów (30 $\mathrm{mln}$ euro), nawadniania i bezpieczeństwa żywnościowego $(27,7 \mathrm{mln})$. Unijne wsparcie miało pozwolić na stopniowe przechodzenie od pomocy humanitarnej do stwarzania możliwości rozwojowych w dziedzinach zdrowia, wody, szkolnego dożywiania ${ }^{7}$ bezpieczeństwa ( $23 \mathrm{mln}$ euro). Inne projekty rozpoczęte w $2013 \mathrm{r}$. i kontynuowane w $2014 \mathrm{r}$. obejmowały reformę wymiaru sprawiedliwości (12 $\mathrm{mln}$ euro) prewencję konfliktową i pojednanie ( $5 \mathrm{mln}$ euro), ukończenie budowy głównej drogi pomiędzy Niono i Timbuktu ( $32 \mathrm{mln}$ euro) oraz współpracę techniczną (4 mln euro) (EUROPAID, 2015)

Komisja Europejska wspiera ponadto misję AFSIMA w ramach Instrumentu na rzecz Pokoju w Afryce $(50 \mathrm{mln} \text { euro })^{8}$, proces pojednania między północą i południem ( $22 \mathrm{mln}$ euro), wyasygnowała również $54 \mathrm{mln}$ euro na doraźne i nagłe potrzeby, $3 \mathrm{mln}$ euro na misję monitorującą przebieg wyborów, a także 600 tys. euro na promocję praw człowieka (EUROPAID, 2015). Od początku kryzysu w 2012 r. Komisja Europejska przekazała do Mali pomoc humanitarną o wartości $184 \mathrm{mln}$ euro, łącznie z $23 \mathrm{mln}$ w ramach Europejskiego Funduszu Rozwoju na dostęp do podstawowych usług jak służba zdrowia, woda, edukacja oraz pomoc żywnościowa dla północnych terenów Mali (stan na luty 2015, Eropean Comission, 2015). Natomiast pomoc humanitarna państw członkowskich od 2013 r. wyniosła kolejne 128,6 mln euro. W 2013 r. Dyrekcja Generalna ds. Pomocy Humanitarnej i Ochrony Ludności (ECHO) KE przeznaczyła 42 mln euro na wsparcie ofiar konfliktu w Mali i w krajach sąsiednich. ECHO angażuje się w inicjatywy zapewniające mieszkańcom północnego Mali dostęp do bezpłatnej i wykwalifikowanej służby zdrowia. Szacuje się, że 230 tys. Malijczyków pozostaje wysiedlonych, wśród nich 143,5 tys. to uchodźcy do innych krajów, natomiast 86 tys. osoby przesiedlone wewnątrz kraju (European Comission, 2015; EUROPAID, 2015). ECHO wspiera

75 mln euro dyrekcja ECHO przeznaczyła na kampanię „Powrót do szkoły”, którą objęto ponad 200 tys. dzieci w regionach Gao, Timbuktu i Kidal, zapewniając regularne szkolne posiłki dla 114 tys. uczniów.

${ }^{8}$ Analizując ewolucję europejskiej polityki rozwojowej w kierunku większej harmonizacji sfer rozwoju i bezpieczeństwa należy zwrócić uwagę na szczególny jej instrument, jakim jest Instrument na rzecz pokoju w Afryce (African Peace Facility - APF), którego finasowanie wspierane jest z EFR. W ten sposób UE wykorzystuje środki rozwojowe na podniesienie zdolności afrykańskich krajów do prowadzenia operacji pokojowych pod auspicjami Unii Afrykańskiej, co pociagga za sobą możliwość finansowania użycia afrykańskich sił pokojowych. Pomocą mogą być pokryte m.in. koszty ich utrzymania w kraju zaangażowania, rozbudowa zdolności, jednakże z wyłączeniem wydatków na cele wojskowe i zbrojeniowe. Jednakże kontrowersje wśród państw czlonkowskich budzi kwestia relatywizacji środków pomocowych w tym kontekście. Dlatego też sugeruje się by w przyszłości takie działania były przedmiotem finansowania z budżetu Wspólnej Polityki Zagranicznej i Bezpieczeństwa UE. 
koordynację akcji humanitarnej i Lotniczej Pomocy Humanitarnej Narodów Zjednoczonych (UNHAS). Uzupełniając działania UNHAS samoloty ECHO dostarczały pomoc do północnych regionów Mali w styczniu 2014 r. Pomoc została utrzymana dla uchodźców w obozach w Mauretanii, Nigrze i Burkina Faso (żywność, produkty nieżywnościowe, woda, opieka zdrowotna). W $2014 \mathrm{r}$. ECHO przeznaczyła ponad $11 \mathrm{mln}$ euro na leczenie ostrego niedożywienia, w rezultacie o połowę zmniejszyła się umieralność dzieci w porównaniu z rokiem 2012 (Eropean Comission, 2015).

\section{Konkluzje}

Kryzys w Mali jest konsekwencją eskalacji narastającego, długotrwałego konfliktu w tym kraju. Już w 2002 r. Departament Stanu USA ostrzegał, że kraj staje się „pożywką" dla radykalnych ekstremistów (Lasconjarias, 2013). Natomiast interwencja w Mali i zaangażowanie społeczności międzynarodowej rysuje widmo kolejnego Afganistanu.

Działania Unii Europejskiej wyznacza powiązanie „bezpieczeństwa z rozwojem” jako kluczowej zasady kompleksowego podejścia UE w zakresie konfliktów i kryzysów zewnętrznych. Bowiem tylko rozwój i eliminacja ubóstwa umożliwia trwały pokój. Zatem ,tworzenie i wzmacnianie warunków politycznych, społecznych i gospodarczych dla stabilności ma zasadnicze znaczenie dla bezpieczeństwa kraju i jest warunkiem wstępnym dla jego rozwoju" (Komisja Europejska, Wysoki Przedstawiciel Unii do Spraw Zagranicznych i Polityki Bezpieczeństwa, 2015, s. 3). Reakcja na malijski kryzys odpowiadała unijnej koncepcji zarządzania kryzysami za pomocą zróżnicowanych instrumentów i zdolności. $Z$ jednej strony zmobilizowane zostały cywilne zasoby do opanowywania kryzysów oraz wojskowe wsparcie dla szkolenia malijskich sił bezpieczeństwa. Z drugiej strony dla przezwyciężenia kryzysu w Mali wzmocniona została współpraca $z$ Unią Afrykańską i w szczególności państwami członkowskimi ECOWAS, a także z ONZ. Jednocześnie wykluczono jakikolwiek udział żołnierzy UE w walkach, nie mówiąc o wykorzystaniu unijnych Grup Bojowych.

Na zagrożenie, że Mali stanie kolejną „,nową twierdzą terrorystów”, czy „drugim Afganistanem", jak stwierdził niemiecki minister współpracy rozwojowej Dirk Niebel (N-TV, 2012; Spiegel, 2012), UE nie była przygotowana w ramach swojego zarządzania kryzysowego. Mając na uwadze brak możliwości osiagnięcia konsensusu dla wykorzystania wieloaspektowych instrumentów cywilnych i wojskowych wobec tego typu wyzwań, ograniczone działanie narażone jest na duże ryzyko porażki w obliczu przeciwnika gotowego na wszystko.

Francja podjęła inicjatywę niezależnie od zaangażowania innych państw UE czy NATO, zdając sobie sprawę że bez militarnej interwencji długofalowe instrumenty przewidziane w unijnej mapie drogowej dla Mali skazane są na porażkę. Mimo przeświadczenia o zasadności francuskiej interwencji nie podjęto decyzji o użyciu sił szybkiego reagowania NATO czy Grup Bojowych UE.

Wypowiedź Sekretarza Generalnego NATO Andersa F. Rasmussena z 18 stycznia 2013 r. w wywiadzie dla Euronews „nie widzę żadnej roli NATO w Mali”, a także decyzja nadzwyczajnego posiedzenia ministrów spraw zagranicznych UE z 17 stycznia 
2013 r. w sprawie przyśpieszenia planowanej od połowy 2012 r., zaakceptowanej w grudniu misji szkoleniowej pokazują rozdźwięk między polityczno-deklaracyjnym wsparciem francuskiej akcji. Wprowadzona formuła, że rozwiązanie kryzysu w Mali ma mieć charakter polityczny a nie militarny, sprawia że powstaje sprzeczność. Choć nie ma nic bardziej politycznego w rozwiązaniu sytuacji kryzysowej niż użycie środków wojskowych, jak zauważył już C. v. Clausewitz.

Zatem wyzwanie wiąże się z podjęciem politycznej decyzji, czy dla uzasadnionego celu, jakim było w tym przypadku niedopuszczenie do powstania kolejnej „twierdzy terrorystów", UE wykorzysta nie tylko cywilne instrumenty reagowania kryzysowego, ale również będzie gotowa do militarnej interwencji dla uzyskania politycznego rezultatu. W obliczu przyszłych konfliktów i kryzysów taka decyzja wydaje się kluczowa, zwłaszcza jeśli prowadzenie dalszych działań politycznych staje się iluzoryczne, tak jak miało to miejsce $w$ przypadku zagrożenia przejęcia kontroli nad całym Mali.

ONZ, UE i NATO uznając kryzys w Mali za „bezpośrednie zagrożenie międzynarodowego pokoju i bezpieczeństwa", a tym samym konieczność reakcji na rosnące terrorystyczne zagrożenie zarówno w Mali, jak i z Mali, powinny - a zwłaszcza UE - dowieść swojego często eksponowanego aktywnego, spójnego i efektywnego zarządzania kryzysowego. Zamiast koncentracji na procesie politycznym i wyznaczaniu mapy drogowej istotne było $i$ jest $w$ dalszym ciagu niedopuszczenie do wzmocnienia sił radykalnych ekstremistów. Należy postawić sobie pytanie czy UE nie utrzymuje Grup Bojowych właśnie dla takich sytuacji kryzysowych, wymagających szybkiej reakcji. W pierwszej połowie 2013 r. w pełnej gotowości był Grupa Weimarska, m.in. z jednostkami z Niemiec, Francji i Polski.

Jeśli państwa członkowskie UE już we wstępnym planowaniu kryzysowym dla Mali od połowy 2012 r. wykluczały własne działania, jeśli nie mogą osiaggnać konsensusu wobec użycia własnych dostępnych sił w przypadku nagłego zaostrzenia kryzysu, to 10 lat po przyjęciu Europejskiej Strategii Bezpieczeństwa i pierwszych misji WPZiB na Bałkanach zasadne jest pytanie o kosztowne utrzymywanie w gotowości dwóch Grup Bojowych w jednym półroczu. W przypadku Mali rozwiązanie tego kryzysu bez wspólnego działania państw członkowskich UE, jest krokiem wstecz dla WPBiO UE, ale także strategicznego zarządzania kryzysowego Sojuszu po ustaleniach szczytu w Lizbonie w 2010 r. i interwencji w Libii w 2011 r. Wytyczną i politycznym celem dla koniecznego działania powinno być niedopuszczenie do powstania „Sahelistanu” - „nowej bezpiecznej przystani” (Heisbourg, 2013), podobnie jak Afganistan dla transnarodowych organizacji terrorystycznych.

\section{Bibliografia}

Crisis in Mali (2014), http://www.responsibilitytoprotect.org/index.php/crises/crisis-in-mali, 10.06.2015.

Decyzja Rady 2014/219/WPZiB z dnia 15 kwietnia 2014 r. w sprawie misji Unii Europejskiej w dziedzinie WPBiO w Mali (EUCAP Sahel Mali).

Decyzja Rady 2015/76/WPZiB z dnia 19 stycznia 2015 r. w sprawie uruchomienia misji Unii Europejskiej w dziedzinie WPBiO w Mali (EUCAP Sahel Mali) i zmiany decyzji 2014/219/WPZiB. 
Dickow H. (2014) Mali, http://www.bpb.de/internationales/weltweit/innerstaatliche-konflikte/ 175842/mali, 10.06.2015.

Deutsche Welle (2015a), Kabinett billigt längeren Bundeswehreinsatz in Mali, 3.06.2015, http:/www.dw.com/de/kabinett-billigt-1\%C3\%A4ngeren-bundeswehreinsatz-in-mali/a-18494403, 20.07 .2015 .

Deutsche Welle (2015b), Mali-Abkommen nährt Hoffnung auf Frieden, 20.06.2015, http:/www.dw.com/ de/mali-abkommen-n\%C3\%A4hrt-hoffnung-auf-frieden/a-18525696, 20.07.2015.

EEAS (2011) European External Action Service, Strategy for Security and Development in the Sahel. http://eeas.europa.eu/africa/docs/sahel_strategy_en.pdf, 20.07.2015.

EEAS (2015a) European External Action Service, http://eeas.europa.eu/csdp/missions-and-operations/index_en.htm, 20.07.2015.

EEAS (2015b), EU Training Mission in Mali, JUNE 2015 EUTM Mali, http://eeas. europa.eu/csdp/ missions-and-operations/eutm-mali/pdf/factsheet_eutm_mali_en.pdf, 10.07.2015.

EEAS (2015c), Mission civile EUCAP Sahel Mali, http://eeas.europa.eu/csdp/missions-and-operations/ eucap-sahel-mali/docs/factsheet_eucap_sahel_mali_en.pdf, 10.07.2015.

Euronews (2013), Rasmussen: 'No role for NATO in Mali', 18.01.2013, http://www.euronews.com/ 2013/01/18/rasmussen-no-role-for-nato-in-mali/, 20.06.2015.

EUROPAID (2015), https://ec.europa.eu/europeaid/countries/mali_en, 20.06.2015.

European Comission (2015), Mali crisis. Humanitarian Aid and Civil Protection, http://ec.europa.eu/echo/files/aid/countries/factsheets/mali_en.pdf, 20.06.2015.

European Defence Agency (2006), An Initial Long-Term Vision For European Defence Capability And Capacity Needs, http://ue.eu.int/ueDocs/cms_Data/docs/pressdata/EN/reports/91135.pdf, 20.07.2015.

European Defence Agency (2009), Future Trends From The Capability Development Plan, $\mathrm{http}: / /$ www.eda.europa.eu/docs/documents/Brochure_CDP.pdf, 20.06.2015

Europejska Strategia Bezpieczeństwa (2003), https://www.bbn.gov.pl/ftp/dok/01/strategia_bezpieczenstwa_ue_2003.pdf, 10.07.2015.

Heisbourg F. (2013), France to the Rescue, „New York Times” 15.01.2013, http://www.nytimes.com/2013/01/16/opinion/global/france-to-the-rescue.html, 20.06.2015.

Koepf T. (2013), Frankreichs 'neue' militärische Interventionspolitik in Subsahara-Afrika (2002-2009), Nomos Verlagsgesellschaft, Baden-Baden.

Komisja Europejska, Wysoki Przedstawiciel Unii do Spraw Zagranicznych i Polityki Bezpieczeństwa (2015), Wspólny komunikat do Parlamentu Europejskiego i Rady. Budowanie zdolności na rzecz bezpieczeństwa i rozwoju - umożliwienie partnerom zapobiegania kryzysom i zarzadzania nimi, Strasburg 28.04.2015

Kubiak K. (2014), Konflikt w Mali. Rebelia Tuaregów, islamiści i międzynarodowa interwencja. http://przeglad.amu.edu.pl/wp-content/uploads/2014/05/pp-2014-1-351-368.pdf, 20.06.2015.

Lacher W., Tull D. M. (2013), Jenseits von Terrorismusbekämpfung, http://www.swp-berlin.org/fileadmin/contents/products/aktuell/2013A09_lac_tll.pdf, 10.05.2015.

Lasconjarias G. (2013), Understanding the Malian Crisis from a Euro-Atlantic Perspective, NDC Research Report Jauary 2013.

N-TV (2012), Keine Kampftruppen in Mali. Koalition will Ausbilder schicken, 23.10.2012, http:/www.n-tv.de/politik/Koalition-will-Ausbilder-schicken-article7553476.html, 20.06.2015.

Rada UE (2012), Konkluzje Rady w sprawie Mali, Bruksela 20 grudnia 2012, http://register.consilium.europa.eu/doc/srv?1=PL\&f=ST\%2017535\%202012\%20INIT, 20.06.2015.

Rada UE (2014), posiedzenie nr 3309, 14-15.04.2014, http:/www.consilium.europa.eu/pl/meetings/fac/2014/04/14-15/. 
Mali 2015 (2015), http://www.africaneconomicoutlook.org/fileadmin/uploads/aeo/2015/CN_data/ Cn_Long_FR/Mali_2015.pdf, 20.07.2015.

Rada UE (2015a), Konkluzje Rady w sprawie Mali, 16.03.2015, komunikat prasowy 124/15, $\mathrm{http} / /$ www.consilium.europa.eu/pl/press/press-releases/2015/03/16-council-conclusions-mali/, 20.06.2015.

Rada UE (2015b), Konkluzje Rady w sprawie Mali, 20.07.2015, komunikat prasowy 605/15, http://www.consilium. europa.eu/pl/press/press-releases/2015/07/20-fac-mali-conclusions/, 25.07.2015.

Spiegel (2012), Mali-Mission: Westerwelle schließt Entsendung von Kampftruppen aus Spiegel, online, 23.10.2012, http://www.spiegel.de/politik/ausland/westerwelle-schliesst-entsendung-deutscher-kampftruppen-nach-mali-aus-a-862978.html, 20.07.2015.

UN Security Council (2012a), Resolution 2071 (2012) On planning for military intervention in Mali (S/Res/2071), 6846 ${ }^{\text {th }}$ meeting, 12 October.

UN Security Council (2012b), Resolution 2085 (2012) Authorizing deployment of a military mission to Mali (S/Res/2085), 6898 $8^{\text {th }}$ meeting, 20 December.

UN Security Council (2013), Resolution 2100, S/Res/2100, 6952 ${ }^{\text {th }}$ meeting, 25 April.

UN Security Council (2014), Resolution 2164, [on extension the mandate of the UNMultidimensional Integrated Stabilization Mission in Mali (MINUSMA) until 30 June 2015/ S/Res/2164, $7210^{\text {th }}$ meeting, 25 June 2014.

UNHCR Mali (2015), http://www.unhcr.org/pages/49e484e66.html, 20.07.2015.

World Report (2015), Mali, Events of 2014, https://www.hrw.org/world-report/2015/country-chapters/mali.

\section{Streszczenie}

Działania UE w obliczu trwającego w ostatnich latach kryzysu w Mali wyraźnie uwydatniają zarówno możliwości, jak i granice unijnej zdolności zarządzania kryzysowego. W styczniu 2013 r. w obliczu zagrożenia secesją północnej części Mali kontrolowanej przez tuareskich rebeliantów Francja podjęła samodzielną interwencję wojskową. Pogłębiający się kryzys humanitarny i bezpieczeństwa w tym kraju, fala uchodźców, groźba powstania kolejnej przystani radykalnych dżihadystów i w konsekwencji dezintegracja malijskiej państwowości wpisuje się w katalog najważniejszych wyzwań, przed którymi stoi obecnie społeczność międzynarodowa i stanowi istotne zagrożenie dla stabilności i bezpieczeństwa międzynarodowego w wymiarze regionalnym i globalnym. O ile UE jest jak najbardziej zdolna do prowadzenia misji w zakresie cywilno-wojskowego zarządzania kryzysowego, o tyle ograniczona jest jej zdolność i wola państw członkowskich do szybkiej i zdecydowanej reakcji w takich sytuacjach jak kryzys malijski.

Słowa kluczowe: UE, WPBiO, kryzys, bezpieczeństwo

\section{The Mali Crisis - a challenge for the EU's Common Foreign, Security and Defence Policy (2012-2014)}

\section{Summary}

This paper explores the role played by the EU in addressing the crisis in Mali. The analysis briefly covers the causes and the outbreak of the crisis, the French-led intervention and the role of regional organisations and the UN's response. The aim is to explore the evolution and humani- 
tarian consequences of the Malian crisis with particular concern for the role played by the EU. The paper concludes with a brief analysis of the limitations of the EU's Common Security and Defence Policy and the lack of political will to generate a concrete fast response as in the case of Mali.

Key words: EU, Mali, CSDP, crisis, security 